\title{
TRANSPORTATION ISSUES IN THE DELIVERY OF GTL PRODUCTS FROM ALASKAN NORTH SLOPE TO MARKET
}

FINAL REPORT

(Reporting Period: 10/1/2001 to 9/30/2002)

Principal Author: Godwin A. Chukwu, Ph.D., P.E.

January, 2004

Work Performed under Cooperative Agreement No. DE-FC26-01NT41248

\author{
Submitted by: \\ Petroleum Development Laboratory \\ University of Alaska Fairbanks \\ P.O. Box 755880 \\ Fairbanks, AK 99775-5880
}

Prepared for:

The US Department of Energy

National Energy Technology Laboratory

P.O. Box 880

Morgantown WV 26507-0880 


\section{TRANSPORTATION ISSUES IN THE DELIVERY OF GTL PRODUCTS FROM ALASKANNORTH SLOPE TO MARKET}

\section{DISCLAIMER}

This report was prepared as an account of work sponsored by an agency of the United States Government. Neither the United States Government nor any agency thereof, nor any of their employees, makes any warranty, express or implied, or assumes any legal liability or responsibility for the accuracy, completeness, or usefulness of any information, apparatus, product, or process disclosed, or represents that its use would not infringe privately owned rights. Reference herein to any specific commercial product, process, or service by trade name, trademark, manufacturer, or otherwise does not necessarily constitute or imply its endorsement, recommendation, or favoring by the United States Government, or any agency thereof. The views and opinions of authors expressed herein do not necessarily state or reflect those of the United States Government or any agency thereof. 


\title{
TRANSPORTATION ISSUES IN THE DELIVERY OF GTL PRODUCTS FROM ALASKANNORTH SLOPE TO MARKET
}

\begin{abstract}
The Alaskan North Slope (ANS) is one of the largest hydrocarbon reserves in the United States where Gas-to-Liquids (GTL) technology can be successfully implemented. The proven and recoverable reserves of conventional natural gas in the developed and undeveloped fields in the Alaskan North Slope (ANS) are estimated to be 38 trillion standard cubic feet (TCF) and estimates of additional undiscovered gas reserves in the Arctic field range from $64 \mathrm{TCF}$ to $142 \mathrm{TCF}$. Because the domestic gas market in the continental United States is located thousands of miles from the ANS, transportation of the natural gas from the remote ANS to the market is the key issue in effective utilization of this valuable and abundant resource. The focus of this project is to study the operational challenges involved in transporting the gas in converted liquid (GTL) form through the existing Trans Alaska Pipeline System (TAPS).
\end{abstract}

A three-year, comprehensive research program was undertaken by the Petroleum Development Laboratory, University of Alaska Fairbanks, under cooperative agreement No. DE-FC26-98FT40016 to study the feasibility of transporting GTL products through TAPS. Cold restart of TAPS following an extended winter shutdown and solids deposition in the pipeline were identified as the main transportation issues in moving GTL products through the pipeline. The scope of work in the current project (Cooperative Agreement No. DE-FC26-01NT41248) included preparation of fluid samples for the experiments to be conducted to augment the comprehensive research program. 


\section{TABLE OF CONTENTS}

CHAPTER

PAGE

Abstract

3

Executive Summary

$1 \quad$ Experimental 6

$2 \quad$ Results and Discussion $\quad 7$

3 Conclusion $\quad 8$

$\begin{array}{lr}\text { References } & 9\end{array}$ 


\section{TRANSPORTATION ISSUES IN THE DELIVERY OF GTL PRODUCTS FROM ALASKANNORTH SLOPE TO MARKET}

\section{EXECUTIVE SUMMARY}

The Alaskan North Slope is one of the largest hydrocarbon reserves in the United States where Gas-to-Liquids (GTL) technology can be successfully implemented. Gas-to-liquids (GTL) conversion technology, where natural gas is chemically converted to transportable liquid products, is an emerging technology that is expected to reach commercialization within the next decade. The proven and recoverable reserves of conventional natural gas in the developed and undeveloped fields in the Alaskan North Slope (ANS) are estimated to be 38 trillion standard cubic feet (TCF). Currently, only a small portion of the produced natural gas of the North Slope of Alaska is used in the oil-field operation, such as gas lift and power generation, and in local sales. The unused portion is injected back into the reservoir for pressure maintenance and oil production. It is expected that as crude oil production on the North Slope continues to decline, approximately 26 TCF of ANS natural gas will become available for gas sales, transportation and/ or conversion to GTL products. This equates to over 4 billion barrels of oil equivalent.

Transportation of the natural gas from the remote ANS is the key issue in effective utilization of this valuable and abundant resource. The throughput of oil through the Trans Alaska Pipeline System (TAPS) has been on the decline and is expected to continue to decline in future. It is projected that by the year 2015, ANS crude oil production will decline to such a level that there will be a critical need for pumping additional liquid from GTL process to provide an adequate volume for economic operation of TAPS.

A three-year, comprehensive research program was undertaken by the Petroleum Development Laboratory, University of Alaska Fairbanks, under cooperative agreement No. DE-FC26-98FT40016 to address the transportation issues involved in moving GTL products through TAPS. A material testing program for GTL and GTL/Crude oil blends was designed following discussions with John Hackworth (UAF consultant on GTL studies) and Alyeska Pipeline Service Company, the TAPS operator. The main objective of the current project (Cooperative Agreement No. DE-FC26-01NT41248) was to augment the comprehensive research program through preparation of additional fluid samples for the material testing program. 


\section{CHAPTER 1}

\section{EXPERIMENTAL}

This project addresses the study of GTL product transportation through the existing Trans Alaska Pipeline System (TAPS). One of the objectives of this project is to select tests and evaluate samples of GTL products and GTL-crude oil blends in order to assess the feasibility of transporting such materials through TAPS. Density and viscosity measurements as functions of temperature are necessary for calculating horsepower requirements. Experimental data on density and viscosity of naturally occurring hydrocarbon mixtures are not well documented. However, measurements on true boiling point (TBP) fractions of various Arab (Amin and Beg 1994) and North Sea Crudes (Dandekar et. al., 1998), Alberta bitumen (Miadoyne et al., 1994) and Saskatchewan oils (Singh et al., 1994) have been reported. Additionally, the predictive capabilities of various viscosity correlations still remain a weak link. Therefore, the need for accurately measured experimental data is indispensable for evaluating the feasibility of transporting GTL products through the TAPS.

Another important GTL testing parameter is the gel strength, which is one of the most important properties necessary to evaluate the feasibility of cold restart of TAPS. The measurement of gel strength gives an indication of the so-called 'cold restart pressure' at which the liquid in the pipeline can yield under the given arctic conditions in Alaska. Thus, bearing in mind the significance of this parameter, gel strengths of various GTL and GTL-ANSC blends need to be determined by the rotating vane technique at different temperatures.

There still exists an uncertainty as to exactly which particular type of GTL product will be the potential candidate for flow through TAPS. A number of GTL product matrix possibilities exist, which are dependent on GTL process options such as catalyst used, process employed, operating conditions and type of GTL product upgrading, and other factors such as gas quality, Alaskan North Slope (ANS) logistics etc. In this study, a GTL sample product was obtained from the US Department of Energy and different fractions of the sample material were used to simulate variation of GTL product types. Thus, we were able to represent a wide range of GTL material that could potentially be produced from a North Slope GTL plant. 


\section{CHAPTER 2}

\section{RESULTS AND DISCUSSION}

Fluid samples for the experiments planned in the comprehensive research project were prepared to represent a wide range of possible GTL output from the proposed GTL plant in the Alaskan North Slope. Fischer Tropsch synthesis for GTL production results in a highly variable liquid composition depending on the exact process used. Therefore, multiple distillate fractions (e.g. $90 \%, 80 \%, 70 \%$ etc.) of the available GTL sample were prepared and blended with ANS crude oil for the material testing program. In addition, the paraffin wax (heavier alkanes) was separated from the wax sample by a modified ASTM-1160 Vacuum Distillation process to produce only a $20 \%$ overhead fraction. This wax fraction was then gravimetrically mixed with the light hydrocarbon GTL liquid in the proportions of $25 \%$ wax distillate $+75 \%$ light GTL and $50 \%$ wax distillate $+50 \%$ light GTL. Thus, twenty-four samples were gravimetrically prepared for the material testing program as per the ratios listed below:

(a) $25 \%$ wax distillate $+75 \%$ light hydrocarbon (LH) GTL

(b) $50 \%$ wax distillate $+50 \%$ light hydrocarbon GTL

(i) sample (a) + crude oil (1:4)

(ii) sample (a) + crude oil (1:3)

(iii) sample (b) + crude oil (1:4)

(iv) sample (b) + crude oil (1:3)

(v) LH sample + crude oil (1:4)

(vi) LH sample + crude oil (1:3)

In the GTL:crude oil blend ratios, smaller proportions of GTL were used because GTL production in the North Slope is expected to be far less than crude oil production in the foreseeable future. Thus, blends containing lower proportions of GTL are likely to flow through TAPS. 


\section{CHAPTER 3}

\section{CONCLUSION}

The scope of work for this project included preparation of GTL and GTL-crude oil blend samples to be used in the material testing program of the comprehensive research project. Two graduate students, Mr. Aaron White and Mr. Jason Westervelt, were funded through this project. Samples of GTL and GTL-crude oil blends were prepared with varying wax content to simulate a wide range of possible product streams generated by a futuristic GTL plant on the Alaskan North Slope. This was a necessary and crucial step in the overall research program because the exact composition of GTL to be produced on the North Slope is not known at this time. 


\section{REFERENCES}

Amin, M. B.; Beg, S. A. Generalized Kinematic Viscosity-Temperature Correlation for Undefined Petroleum Fractions of IBP- $95{ }^{\circ} \mathrm{C}$ to $455{ }^{\circ} \mathrm{C}^{+}$Boiling Ranges. Fuels Science \& Technology International 1994, 12, 97-129.

Dandekar, A., Andersen, S.I.A. and Stenby, E. Measurement of Viscosity of Hydrocarbon Liquids Using a Microviscometer. 1998. J. Chem. Eng. Data, 43 (4): 551.

Malone, R.D. and Komar, C.A. (Eds.): "Natural Gas to Liquids" Technology Status Report, Morgantown Energy Technology Center, US DOE, DOE/METC-89/0265, Jan. 1989.

Miadoyne, A.; Singh, B.; Puttagunta, V. R. Modelling the Viscosity-Temperature Relationship of Alberta Bitumen. Fuels Science \& Technology International 1994, 12, 335-350.

Robertson, E.P., Thomas, C.P. and Avellanet, R.A.: "Economics of Alaska North Slope Gas Utilization Options," paper presented at the SPE Western Regional Meeting, Anchorage, Alaska, May 1996.

Sharma, G.D., Kamath, V.A., Patil, S.L. and Godbole, S.P.: "The Potential of Natural Gas in the Alaskan Arctic," paper SPE 17456, Proceedings of the SPE California Regional Meeting, Long Beach, CA, March 1988, pp. 515-523.

Singh, B.; Miadoyne, A.; Huang, S. S.; Srivastava, R.; Puttagunta, V. R. Estimating Temperature and Pressure Effects on Viscosity of Saskatchewan Heavy Oils. Fuels Science \& Technology International. 1994, 12, 693-704. 